\title{
Eye health attention of children with developmental disorders in early intervention services: barriers and facilitators
}

\author{
Atenção à saúde ocular de crianças com alterações no \\ desenvolvimento em serviços de intervenção precoce: \\ barreiras e facilitadores
}

\author{
Gabriela Cordeiro Corrêa do Nascimento', Heloisa Gagheggi Ravanini Gardon Gagliardo²
}

\begin{abstract}
Objective: To identify factors that influence on the early detection of visual impairment and in early intervention onset for children with developmental disorders. Methods: The study consisted of a exploratory and descriptive survey, which included the use of questionnaires with institutional representatives, professional team of early intervention and mothers or caregivers of children served in these services. The data received statistical analysis through software SAS Statistical Analysis System 9.3, Wolfram Mathematica and Microsoft Excel. The sample consisted of 434 subjects (19 institutional representatives, 142 professionals of the early intervention services and 273 mothers/ caregivers of children served). Results: The results showed statistical values of $p=0.0119$ for the realization of eye test with regard to the beginning of early intervention. The mother receive guidance on the development of vision obtained values of $p$-value $=0.0106$ for early intervention start and values of $p=0.0061$ for the first visit to the ophtalmologist. Conclusion: Realise the eye test constitutes as a facilitating factor for the onset of early intervention and have an exclusively visual impairment and attend private institution as a barrier. Late entry into early intervention service adversely affects the age of first ophthalmologic consultation. The mother receive guidance on the development of vision showed as a facilitating factor for the first visit to the ophtalmologist and start of timely intervention. The field of eye health constitutes as public health demand and requires attention to actions and educational programs directed to families, professionals and institutional managers who provide services to children.
\end{abstract}

Keywords: Eye health; Early intervention (Education); Developmental disabilities; Child

\section{RESUMO}

Objetivo: Identificar fatores que influenciam na detecção precoce de deficiência visual e o início da intervenção precoce de crianças com alterações no desenvolvimento. Métodos: $\mathrm{O}$ estudo constituiu-se de levantamento, exploratório e descritivo, que contou com a aplicação de questionários com representantes institucionais, profissionais da equipe dos serviços de intervenção precoce e mães ou cuidadores das crianças atendidas. Os dados receberam tratamento estatístico através dos softwares Sistema de Análise Estatística SAS 9.3, Wolfram Mathematica e Microsoft Excel. A amostra constituiu-se de 434 sujeitos (19 representantes institucionais, 142 profissionais dos serviços e 273 mães/cuidadores das crianças atendidas). Resultados: A análise dos resultados revelou valores estatísticos de $p$-valor=0,0119 para a realização do teste do olhinho no que se refere ao início da intervenção precoce. A mãe recebe orientação quanto ao desenvolvimento da visão que obteve valores de $p$-valor $=0,0106$ para início da intervenção oportuna e valores de $p$-valor $=0,0061$ para primeira consulta ao oftalmologista. Conclusão: Realizar o teste do olhinho constituiu-se fator facilitador para o início da intervenção precoce e ter uma deficiência exclusivamente visual e frequentar instituição privada como barreira. A entrada tardia em serviço de intervenção precoce afeta negativamente a idade da primeira consulta oftalmológica. A mãe recebe orientação quanto ao desenvolvimento da visão que revelou-se fator facilitador para a primeira consulta ao oftalmologista e para início da intervenção oportuna. O campo da saúde ocular constitui-se demanda da saúde pública e requer ações e programas educativos direcionados aos familiares, profissionais e gestores institucionais.

Descritores: Saúde ocular; Intervenção precoce (Educação); Deficiências do desenvolvimento; Criança

\footnotetext{
${ }^{1}$ Department of Occupational Therapy, Universidade Federal do Paraná, Curitiba, PR, Brazil.

${ }^{2}$ Faculdade de Ciências Médicas, Universidade Estadual de Campinas, Campinas, SP, Brazil.

Institution where the study was carried out: Universidade Estadual de Campinas, Campinas, SP, Brazil.

${ }^{1}$ The study is part of a large study investigating the "Attention to eye health of children with developmental alterations in Curitiba-PR", approved by the Ethics Committee on Human Research of Faculdade de Ciências Médicas da Universidade Estadual de Campinas (FCM- UNICAMP), under opinion No. 131.74 of October 2012.

The authors declare no conflicts of interests.
}

Received for publication 18/05/2016 - Accepted for publication 27/07/2016 


\section{INTRODUCTION}

$\mathbf{T}$ The World Health Organization (WHO) estimates that $4.25 \%$ of the world's population (approximately $285,000,000$ people) are affected by some degree of visual impairment, with $80 \%$ of cases of visual impairment being avoidable, and being able to be prevented or cured ${ }^{(1)}$. In Brazil, the 2010 Census pointed out that the severe visual impairment was more focused on the Brazilian population, reaching $3.5 \%$ of those reporting having no ability or great difficulty to see ${ }^{(2)}$. In the city of Curitiba-PR, the incidence of people with some degree of visual impairment reached $15.3 \%$ of the total population (approximately 268,000 people) $)^{(3)}$. However, the same survey indicates no data for people with multiple disabilities.

The total or partial lack of sight in childhood can interfere with psychomotor, cognitive, and social development, and with the acquisition of the language by the child, which in turn are key aspects to the process of independence of the individual ${ }^{(4)}$.

Thus, the need to recognize the field of eye health as a public health demand is described by several authors ${ }^{(5-8)}$, primarily due to the deep impact that the visual changes entail for the person, the family and society ${ }^{(6-8)}$.

Eye health practices seek the dissemination of fundamental knowledge in order to strengthen both individual and collective levels, requiring participative attitude of the population, "leading to the construction of transformative practices of the current condition"(9). The authors conclude that, involving multidisciplinary knowledge about the eye health area and putting them available to the population, the horizon expands to the construction of new public policies to promote eye health, as well as new knowledge and new practices.

Considering the impact of visual impairment in the development and learning of the individual, we highlight the need for prevention, early identification and timely intervention of such changes ${ }^{(10,11)}$.

Ventura et al. ${ }^{(12)}$ state that the association between visual impairment and other impairments is frequent. It is known that the impact of said changes on people with multiple impairments is high, occurring in greater proportion when compared to other people ${ }^{(13,14)}$.

The lack of attention to eye health of people with multiple impairments may be related to the false idea that, when compared to the big picture, the eye health is not important. The difficulty in detecting ocular changes in that group of people is linked to factors such as: lack of information by the family about the importance of ophthalmologic follow-up for these people; difficulty to access specialized services; difficulty to carry out the examinations; and difficulty in obtaining visual responses by this group of people ${ }^{(14)}$. Studies have indicated that a significant number of people with impairments have never undergone or later underwent eye exams ${ }^{(13-16)}$.

Thus, the present study aimed at identifying factors to influence the early detection of visual impairment and the beginning of early intervention of children with changes in development.alterações no desenvolvimento.

\section{Methods}

The present research is an exploratory, descriptive, quantitative-in-nature study, being a survey. The data collection was made in the city of Curitiba-PR from February to July 2013, in the premises of institutions providing services of early intervention to children with changes in development who have agreed to participate in the study. The participation of the subjects was by signing the Informed Consent.

The survey had three groups of subjects: $a$ ) representatives of institutions taking care of children with development changes and having early intervention service in the city of Curitiba-PR; b) professionals from the team of early intervention service; and c) mothers or caregivers of the children attended in this service.

Group $a$ included the institutional caregivers who knew how to answer questions relating to the institution and the services provided. In group $b$, the professionals from the team of early intervention, of both sexes, from the areas of health, education or social assistance. Group $c$ included mothers or caregivers closest to the children attended in the early intervention service and who could answer questions related to the medical history and characteristics of the child. The sample consisted of 434 subjects (19 institutional representatives, 142 service professionals, and 273 mothers/caregivers of children attended).

The data collection instruments were three structured questionnaires - one for each group of subjects - with questions relating to the institution, the professional practices, and the characteristics of mothers/caregivers and children attended, drawn based on the data that intended to be obtained and the literature related. The instruments have undergone a pre-test phase in a pilot project, going through modifications to constitute the final instruments of data collection.

Questionnaires 1 and 2 were self-applicable, and were delivered along with guidelines for filling it, and were subsequently collected. Questionnaire 3 referring to mothers or caregivers of children was applied directly to the subjects by researchers or by trained volunteers.

The data obtained with the application of questionnaires was tabulated in the spreadsheet program Microsoft Office Excel 2007, and received statistical treatment using the software Statistical Analysis System SAS 9.3, Wolfram Mathematica and Microsoft Excel. The tests used for the analysis were the Student T-test and the Fisher exact test. The index of significance was of 5\%.

\section{ResULTS}

As noted in the estimate, the analysis pointed out that children who attend a private institution have an average age of onset in early intervention 6.61 months older than those who attend a public or third sector institution; children who underwent the red reflex testing initiate early intervention with an average age 2.29 months younger than those who did not; children with excusively visual impairment initiate early intervention with an average age 5.96 months older than those with other impairments; and children whose mothers were oriented on the development of sight tend to initiate early intervention with an average age 2.27 months younger than those whose mothers were not guided.

Following the same logic, the analysis of association between age of first appointment with the ophthalmologist (age of interest) and factors related to the institution, professionals and mothers/caregivers, again needed to be adjusted to a Linear Regression Model. By eliminating the factors that were not significant (age of mother, nature of the institution, type of impairment, and red reflex testing), the data shown in table 2 was obtained, highlighting the factors that influence the age of 
Table 1

Influence of factors on age of onset in early intervention after selection of covariates

\begin{tabular}{lccc}
\hline Factors & Estimate & Statistical T value & p-Value \\
\hline Reference group & 9.53 & 11.92 & $<0.0001$ \\
Received guidance on the development of sight & -2.27 & -2.57 & 0.0106 \\
Undergone the red reflex testing & -2.29 & -2.53 & 0.0119 \\
Private institution & 6.61 & 3.70 & 0.0003 \\
Exclusively visual impairments & 5.96 & 3.41 & 0.0007 \\
\hline
\end{tabular}

the first appointment with the ophthalmologist.

It is worth mentioning that initially the aim was the relationship between age of interest and factors such as: proportion of professionals referring to an ophthalmologist; proportion of professionals taking a complementary course on habilitation or rehabilitation of the visually impaired patients; proportion of professionals acting in the field of promotion of child eye health; and proportion of professionals taking some action in the prevention of visual impairments. However, it was found that the proportions defined were not explanatory variables. It is believed that this stems from the fact that the sample size of professionals performing the aforementioned is significantly low.

Based on the estimation data, it is possible to affirm that: each month more on the age of entry in the early intervention service results in 10.2 days ( 0.34 months) more on the age of first appointment; and children whose mothers were guided on the development of sight tend to have their first appointment at an average age of 2.19 months younger than those whose mothers

Table 2

Influence of factors on age of first appointment with the ophthalmologist after selection of covariates

\begin{tabular}{lccr}
\hline Factors & Estimate & Statistical T value & p-Value \\
\hline Reference group & 5.05 & 7.17 & $<0.0001$ \\
Age at the beginning of early intervention & 0.34 & 6.18 & $<0.0001$ \\
Received guidance on the development of sigh & -2.19 & -2.70 & 0.0061 \\
\hline
\end{tabular}

did not receive such guidance.

\section{DisCUSSION}

From the joint analysis of the factors and type of influence on the age for early intervention it was possible to identify the fact that attending an institution of private nature and having an exclusively visual impairment are barrier factors to the early onset of this type of service, which may hinder or impair treatment and, consequently, the child's development. According to this analysis, it was also possible to establish that carrying out the red reflex testing and providing the mother guidance on the development of sight are facilitator factors for an earlier onset of this type of service, and can facilitate and optimize the treatment and development of the child.

The age difference between the onset of children in the early intervention service and those who attend a private institution was significant, and may happen 6 months later than children who attend institutions of other kinds. In order to interpret this result, some hypothesis were created: the referral of customers to private institutions is late; the search or referral demand to such institutions is higher causing a wait for effective entry of children in this service; or the customers demand private institutions only after seeking for public services without being attended. However, no scientific theoretical frameworks were found to explain or justify said hypotheses. On the other hand, it is necessary to consider two aspects: most private institutions identified in this study are characterized as non-profit institutions; and the nature of the institutions was rated by their representatives. The name of the nature of the institutions as first, second and third sector, where the private non-profit institutions are, is still a divisive issue. Despite the apparently clear division between First Sector (State), Second Sector (Private Sector) and Third Sector (Civil Society) - adopted for the preparation of the instruments of this study - the misconceptions on the subject arise mainly from conceptual and theoretical confusion about the latter. According to Ferreira and Ferreira ${ }^{(17)}$, one of the aspects responsible for this situation arises from the use of different names of institutions belonging to the third sector, among them: non-governmental organizations (NGOs), civil society organizations (CSOs), civil society organizations of public interest (CSOPIs) and non-profit organizations (NPOs).

Having only visual impairment was found to be a barrier, since the entry age of the child in the early intervention service ends up being almost six months later than children who do not have only visual impairment. To address the feelings experienced by the family to the birth of a child with visual impairment, Gagliardo et al. ${ }^{(18)}$ point out that these feelings can make the family delay the search for the habilitation service, prioritizing the search for the cure or an "immediate medical solution" or a more favorable diagnosis. According to the authors, this period can lead to consequences for the child's development as a whole, and make parents not receive the support and guidance needed during this period of development. Despite extensive discussion on the importance of early intervention of children with some degree of visual impairment, studies have shown a gap between diagnosis and onset of intervention ${ }^{(19)}$. In a study with parents of children with low vision, the average age of children at the time of identification of the visual impairment was 2.8 months (ranging from 0 to 6 months). However, the onset of visual stimulation treatment occurred on average at 13.4 months 
(ranging from 1 to 33 months) ${ }^{(19)}$.

The red reflex testing proved to be a facilitator to the early entry in the intervention services, which may be related to the fact that the test, according to the current state legislation, should be carried out during maternity ${ }^{(20)}$, and may raise early evidence of pathologies that can lead to losses in the development, requiring treatment and early intervention. However, no theoretical frameworks were identified to ratify or oppose this hypothesis. It should be noted that the red reflex testing is configured as one of the main actions to prevent injuries to the eye health ${ }^{(21)}$.

The guidance to the mother or other caregivers about the development of sight proved to be a facilitator. Information about the child's development and which factors may interfere with the development of the same seems to be an action of health education addressed to all professionals working with these children $^{(22)}$. Authors highlight the importance of disseminating to the population information on eye health stating that the ophthalmological prognosis often depends on the knowledge of the presence of ocular changes and proper care of the disease ${ }^{(23)}$. The benefits of appropriate information and guidance go from the ability to face problems and difficulties to the active participation of parents and caregivers in the treatment and follow-up of children ${ }^{(4,22,24)}$.

Besides the positive aspects to the global development of the child provided by early intervention services described by different authors ${ }^{(25-27)}$, Fiamenghi et al. ${ }^{(24)}$ also point out the benefits of parental participation in these programs by stating that "[...] they help increase information and adaptation resources to create the possibility of sharing their experiences with others who live a similar reality."(24). In this sense, in a study to analyze the effectiveness of an early intervention program for families of children with impairments, we concluded that this type of program can be of great value to the adaptation of parents, in particular in the first 18 months of the child's life, highlighting that compared to the control group the group of parents who participated in a program of early intervention had symptoms of emotional stress, depression and anxiety softened, and presented better adaptation to the situation of disability of the child ${ }^{(28)}$.

At least two of the primary goals of the early intervention mentioned by Franco ${ }^{(26)}$ can comprise the guidance to parents, family members and caregivers as an essential tool, namely: “[...] creating more enabling conditions of good development to eliminate or reduce the risk; [...] strengthen good relations and family responsibilities by promoting a good emotional support base $[\ldots]$ "(26). Children with changes in development, or at risk of developing them, should receive support from multiprofessional teams in reference centers aiming at early detection and intervention ${ }^{(29)}$. Therefore, the role of the multidisciplinary team in this context is key, and the understanding of practitioners in relation to their role in the promotion of knowledge and understanding of parents and other caregivers is crucial ${ }^{(22)}$.

By jointly analyzing what kind of influence the factors have on the age at which the child has their first appointment with the ophthalmologist it was possible to identify that starting early intervention with older age was established as a barrier to early follow-up with the ophthalmologist, which could harm or hinder the eye health in a timely manner. It was possible to guide the mother about the development of sight as a facilitator agent for an early visit to the ophthalmologist, giving attention to the eye health and optimizing the outcome of visual and global development of the child.

The fact of age of entry into a service being a barrier to the early arrival to an ophthalmologist may be related to certain factors. Being part of a program of early intervention may require or take the mother or caregiver to get a more complete diagnosis or raise the possibilities of the child having a visual change, and consequently going to an ophthalmologist. Another aspect that may delay the arrival of the child to an early intervention service and postpone the visit to an ophthalmologist may be related to the acceptance period of the child's condition by the family. Considering children with multiple impairments, the fact may be related to an initial attempt to solve clinical problems, considered the most urgent, delaying the search for early intervention and, consequently, the visit to the ophthalmologist, or not putting the appointment with this professional in first place ${ }^{(15,18)}$. In the study of Gato et al. ${ }^{(16)}$, the authors concluded that children diagnosed with cerebral palsy are referred belatedly to the ophthalmologist, which decreases the possibilities of full development of sight.

The guidance to the mother about the development of sight again proved to be a facilitator. This guidance can gather information about the possibility of children with other developmental disorders also having visual changes, leading to the search for this expert. In this sense, Nobre and Gagliardo ${ }^{(15)}$ state that the arrival at a visual stimulation service is late in the case of children with multiple impairments. The authors say this event, among other reasons, are due to "[...] the severity of neurological cases, difficulty of access to specialist centers, difficulty to define the diagnosis $[\ldots]$ "(15).

Noble et al. ${ }^{(4)}$ described in their research that the majority of the population studied $(31 \%)$ was attended for the first time in the low vision service between 7 and 12 months of age, followed by the age groups between 13 and 18 months (22\%); between 1 and 6 months (15\%); between 19 and 24 months (12\%); and over 25 months $(8 \%)$. The same authors state that this intervention should begin in the first year of life in order to improve not only the visual function, but the overall development of the child. Although the study did not bring data about the age of the first appointment the ophthalmologist, it stresses the importance of welcoming and guiding the mothers, considering their role in the identification of problems, and as facilitators of the development of the child, leading to feelings of competence in relation to the care of their children.

In order to early detect the visual changes, the authors highlight the importance of the professionals and family ${ }^{(15,25)}$, and emphasize that the services provided to families shall provide the knowledge, the skills and the support necessary to defend the rights and needs of children ${ }^{(25)}$.

Remígio et al. ${ }^{(14)}$ state that the lack of information to the families about the importance of ophthalmological follow-up can be one of the causes of a considerable amount of children in the study never being in an appointment with an ophthalmologist. Ventura et al. ${ }^{(30)}$ highlight the relevance of more incisive guidance to parents, especially in relation to the importance of specialized ophthalmological follow-up of children at high risk of developing eye changes.

Although sight develops until the age of $7^{(21)}$, different developmental authors and scholars point out that the first year of life is a critical period for the visual development ${ }^{(15)}$. Thus, early detection of visual impairment and early intervention are critical in the development of children, minimizing the consequences of these changes ${ }^{(15,21)}$. 


\section{ConcLusion}

The study of the relation between the data of institutions, professionals, mothers and children made it possible to identify that such factors act in a diverse way, influencing or not the children's entry age to early intervention services and the age of first appointment with an ophthalmologist. Thus, according to this study, it was concluded that the red reflex testing and the guidance given to the mother as to the development of sight are factors that act as facilitators of appropriate onset at early intervention services. Having an exclusively visual disability and attending a private institution are barrier factors to the timely entry in this type of service. The guidance to the mother about the development of sight is a facilitator for the early visit to the ophthalmologist, and the late entry in an early intervention service adversely affects the age of first appointment with this professional.

The field of eye health, in addition to be being a public health demand, deserves particular attention with the clientele studied due to the high rate of association between visual changes in children and other changes in development. In this sense, it is necessary to direct actions, efforts and resources for educational and training measures in this area of knowledge to professionals who are directly linked to the provision of services to this clientele. Considering the actions of eye health as being of primary health care, it is necessary to emphasize the importance of preventive actions and the promotion of eye health to be carried out by service professionals who provide initial care and infant monitoring, such as the basic health units.

\section{ACKNOWLEDGEMENTS}

The authors thank the institutions that allowed the completion of the present study, as well as the professionals and mothers or caregivers who agreed to participate voluntarily.

\section{ReferenCeS}

1. World Health Organization. Visual Impairment and Blindness 2010-Fact Sheet Global Data 2010 [Internet]. [cited 2015 Aug 1]. Available from: www.who.int/blindness/data_maps/ VIFACTSHEETGLODAT2010full.pdf

2. Instituto Brasileiro de Geografia e Estatística. Censo demográfico: resultados preliminares de amostra. Comunicação social, 16 de Novembro de 2011. IBGE. [citado 2012 Fev 18]. Disponível em: www.ibge.gov.br/home/presidencia/noticias/ noticia_visualiza.php?id_noticia $=2018 \&$ id_pagina $=1$

3. Instituto Brasileiro de Geografia e Estatística. Cidades@ [Internet]. IBGE. [citado 2012 Fev 15]. Disponível em: www.ibge.gov.br/cidadesat/link.php?uf=pr

4. Nobre MI, Montilha R, Figueiredo M, Maciel DP, Carvalho KM. Atendimento de terapia ocupacional em serviço de visão subnormal: caracterização dos usuários. Rev Benjamin Constant. 2009; 43.

5. Vargas MA, Rodrigues ML. Perfil da demanda em um serviço de Oftalmologia de atenção primária. Rev Bras Oftalmol. 2010; 69(2):77-83.

6. Zin AA, Verçosa I, Ventura LM de O, Graziano R. Causas da baixa visão e cegueira nas diferentes faixas etárias. Sessão A Causas de baixa visão e cegueira durante a gestação, parto e no recém-nascido. In: Kara-José N, Rodrigues ML, editores. Saúde ocular e prevenção da cegueira: Rio de Janeiro: Cultura Médica; 2009: p. 38-54.
7. Salomão SR, Mitsuhiro MR, Belfort Jr R. Visual impairment and blindness: an overview of prevalence and causes in Brazil. An Acad Bras Ciênc. 2009; 81(3):539-49.

8. West S, Sommer A. Prevention of blindness and priorities for the future. Bull World Health Org. 2001; 79(3): 244-8.

9. Sperandio AMG, Souza TF de, Breno E, Mendes LC, Pereira ARS, Machado AC, et al. A Universidade colaborando na construção de um projeto de promoção da saúde: relato de experiência de um grupo de alunos de Medicina da Unicamp - Campinas, SP, Brasil. Rev Bras Educ Med. 2006; 30(3): 200-8.

10. Endriss D, Ventura LM, Diniz JR, Celino AC, Toscano J. Doenças oculares em neonatos. Arq Bras Oftalmol. 2002; 65(5):551-5.

11. Costa E de PF, Höfling-Lima AL. Desenvolvimento da Visão. Como a visão se desenvolve. In: Kara-José N, Rodrigues M de LV (ed). Saúde Ocular e Prevenção da Cegueira: Tema oficial do XXXV Congresso Brasileiro de Oftalmologia - 2009. Rio de Janeiro: Cultura Médica; 2009: p. 9-14.

12. Ventura R, Ventura L, Brandt C, Ferraz D, Ventura B. Experiência em projeto: "Enxergando através das mãos". Arq Bras Oftalmol. 2007;70(5):823-6

13. Jorge PA, Ventura LM, Teló CR, Sarmento AG, Rego PR. Características clínicas e oftalmológicas de indivíduos com necessidades especiais institucionalizados no estado de Pernambuco, Brasil. Rev Bras Oftalmol. 2011; 70(2):93-8.

14. Remígio MC, Leal D, Barros E, Travassos S, Ventura LO. Achados oftalmológicos em pacientes com múltiplas deficiências. Arq Bras Oftalmol. 2006; 69(6): 929-32. Disponível em: http://www.scielo.br/ pdf/abo/v69n6/ a25v69n6.pdf

15. Nobre MI, Gagliardo HG, Carvalho KM, Botega MB, Sampaio PR. Múltipla deficiência e baixa visão. Rev Neuroc. 1998; 6(3):11-3.

16. Gato MI, Teixeira E, Pereira KM, Gagliardo HG. Atenção à saúde ocular de crianças com alterações neurológicas: relevância da avaliação oftalmológica. Temas Desenvolv. 2008; 16(93):100-13.

17. Ferreira MM, Ferreira CH. Terceiro setor: um conceito em construção, uma realidade em movimento. Anais da Semana do Contador de Maringá [Internet]. 2006 [citado 2014 Nov 7]. Disponível em: www.dcc.uem.br/semana2006/anais2006/ Anais_2006_arquivo_30.pdf

18. Gagliardo HG, Nobre MI. Intervenção precoce na criança com baixa visão. Rev Neuroc. 2001; 9(1):16-9.

19. Lamas FM, Sampaio PR, Rehder JR. Características e percepções de pais de lactentes portadores de baixavisão. Pediatria (São Paulo). 2010; 32(3):173-6.

20. Paraná (Estado). Secretaria Estadual de Saúde-SESA. Resolução $n^{\circ} 367$ de 24 de agosto de 2009. Regulamenta a realização do Exame de diagnóstico clínico de Catarata Congênita através de Reflexo Vermelho" (Teste do Olhinho).

21. Sperandio AM. Promoção da saúde ocular e prevenção precoce de problemas visuais nos serviços de saúde pública. Rev Saúde Pública. 1999; 33(5):513-20.

22. Vieira NG, Mendes NC, Frota LM, Frota MA. O cotidiano de mães com crianças portadoras de paralisia cerebral. RBPS. 2008; 21(1):55-60.

23. Temporini ER, Kara-José N, Gondim EL, Dantas FJ. Conhecimentos sobre saúde ocular entre profissionais de um hospital universitário. Medicina (Ribeirão Preto). 2002; 35(1): 53-61.

24. Fiamenghi Jr GA, Messa AA. Pais, filhos e deficiência: estudos sobre as relações familiares. Psicol Cienc Prof . 2007; 27(2): 236-45.

25. World Health Organization - UNICEF. Early childhood development and disability: a discussion paper. [Internet]. 2012 [cited 2015 Aug 8]. Available from: www.apps.who.int/iris/bitstream/ 10665/75355/1/9789241504065_eng.pdf

26. Franco V. Dimensões transdisciplinares do trabalho de equipe em intervenção precoce.Interação Psicol. 2007: 11(1):113-21.

27. Franco V, Melo M, Apolonio A. Child's development problems and early intervention. Educ Rev. 2012; (43):49-64. 
28. Pelchat D, Lefebvre H. A holistic intervention programme for families with a child with a disability. J Adv Nurs. 2004; 48(2):124-31.

29. Miranda LP, Resegue R, Figueiras AC. A criança e o adolescente com problemas do desenvolvimento no ambulatório de pediatria. J Pediatr (Rio J). 2003;79(1):33-42.

30. Ventura LM, Travessos S, Ventura AG, Trigueiro L, Marques S. Um programa baseado na triagem visual de recém-nascidos em maternidades Fundação AltinoVentura 2000. Arq Bras Oftalmol. 2002;65(6):629-35.

\section{Corresponding author:}

Gabriela Cordeiro Corrêa do Nascimento.

Av. Lothário Meissner, 632. Universidade Federal do Paraná. Campus Botânico, Bloco Didático II,

Departamento de Terapia Ocupacional. Bairro J

ardim Botânico, Curitiba, PR, Brazil. ZIP Code: 80210-170.

E-mail: gabriela.correa@ufpr.br 